\title{
Impact of the New European Union Landfill Directive on the Baltic Sea Region
}

\author{
Bertil Paulsson \\ HB INTEC, Sweden \\ William Hogland \\ University of Kalmar, Sweden
}

\begin{abstract}
The Baltic Sea region with population exceeding 100 million which in the future will constitute about one quarter of the population in the European Union if Estonia, Latvia Lithuania and Poland are accepted as members.

These countries in the eastern part of the Baltic Sea region are foreseen a rapid economic and technical development. Technologies and industries from different parts of the world are invading and the generation of waste will probably increase drastically if measures for avoidance are not taken.
\end{abstract}

Applying the EU Directive 75/442 EEC on waste, witch current amendments, on the presumptive new members will imply drastic changes for the countries concerned, environmentally as well as economically. In addition an EU Directive 1999/31/EC on the landfilling of waste is decided April 26 1999. The new Directive indicates a substantial reduction of the amount of waste ending up at landfill sites. Member countries of the union have started to prepare them selves for the new situation. Countries interested in becoming members might however not be aware of the cost of the new requirements. Investigations of the situation in these countries indicates that upgrading of their waste management to EU standard will require huge economic resources.

Implementation of a new landfill system and development of close down programme for existing old dumps including post closure environmental control will demand economic resources and import of technology and technical education.

According to the landfill Directive as little landfilling as possible should be carried out which means that the waste must be handled with other methods that are not commonly used in all countries. Those new technologies will probably to high extent be imported from the EU countries rather then developed and manufactured locally. The new technologies introduced must be adopted to the local situation. 


\section{INTRODUCTION}

1) Extract from; Analysis of decision support system for the treatment and disposal of solid urban waste. Report EUR 16468 EN, 1996

2) Extracted from; Proposal for a Council Directive of Landfill Waste. Commission of the European Communities. Brussels, 05.03.1997 COM(97) 105 final

The Municipal Solid Waste Management System is intrinsically complex, because it involves various connected problems and must achieve objectives which are often in conflict.

The difficulties which arise in setting up solid waste treatment and disposal systems are well known as is the scarcity of such systems as regards quantities to be managed.

The site decision makers have to be able to justify adequately the choice of areas which, because of their characteristics, are most suitable for plants with considerable environmental and social impact. In effect, one of the main difficulties comes from the opposition of the people living near the sites intended to host these plants: the so-called "NIMBY" (Not In My Back Yardi) syndrome". This general opposition to sites in nurtured by a management organisation which does not always seem capable of presenting a convincing overall justification.

There are also several management choices, such as waste reduction, recycling of materials, recovery of energy and so on. However, it can be stated that, although many obstacles may be overcome, a large mass of urban waste must still be sent for disposal.

There is thus considerable need for disposal services and a wide space for the development of management techniques correctly supported by scientific tools which help to evaluate the environmental policy choices. The final goal of this kind of evaluation is always a decision.

Moreover, given the awareness that this evaluation cannot be reduced to the optimisation of just one parameter, the multicriteria decision context is that in which formal approaches and practical applications in the field of applied sciences and complex engineering processes have mainly been developed. In the 1989 the Commission of the European Communities presented a Proposal for a Community Strategy for Waste Management focused on the need to harmonise standards for waste management facilities on the basis of a high level of environmental protection.

The Council of Ministers adopted the main guidelines of this strategy in a Resolution of 7 May 1990. An important element was the optimisation of the final disposal of waste. The strategy stressed as key priority that the final disposal of waste should be applied as an option of the last resort.

Consequently the commission presented a proposal for a Directive on the landfill $\mathrm{f}$ waste in order to ensure that the Member States adopt a homogenous policy related to landfills and that standards should be harmonised throughout the Community.

In the 1996 the Commission adopted a Communication on the review of the Community Strategy for Waste Management. This Strategy confirmed the principles stated in the 1989 Strategy, while introducing additional means for improving waste management in the Union. The new Directive 1991/31/EC on the landfill of waste takes into account both developments in the waste area as reflected in the review of the Community Strategy of Waste management 
of 1996 and legislation or updated legislation adopted since the discussion of the original Proposal.

\section{ENVIRONMENTAL IMPACT FROM LANDFILLING}

1) Extracted from; Proposal for a Council Directive of Landfill Waste. Commission of the European Communities. Brussels, 05.03.1997 COM(97) 105 final

The 1996 Commission Communication on the review of the Community Strategy for Waste Management confirmed the hierarchy of waste principles established by the Communication of 1989. The principle of prevention of waste generation remains the first priority, followed by recovery and finally by the safe disposal of waste i.e. landfilling. In the Community Waste Strategy landfilling represents the option of last resort because it can have substantial negative impacts on the environment. The most important include emissions of hazardous substances to soil and ground water, emissions of methane into the atmosphere, dust, noise, explosion risks and deterioration of land. Landfilling as a waste management method has no effect on the prevention of waste and does not make use of waste as a resource, which has a higher priority in the Community Waste Strategy.

\section{Objectives of the landfill Directive}

Article $130 \mathrm{r}$ (2) of Treaty requires environmental policy to be based on a high level of protection. The main objective of the Proposal is to ensure high standards for the disposal of waste in the European Union and to simulate waste prevention via recycling and recovery of waste. Of key importance is the objective of creating a level playing field for the cost of disposal which consequently will prevent the unnecessary transport of waste. Today in Member States the price charged for landfilling of waste does not appear to reflect the actual cost for the environment and for society in general. In the new Directive, Member States are required to ensure that externalises are internalised when the cost for landfilling of waste is estimated.

The Community has adopted provisions for the incineration of waste in Directives $89 / 369 \mathrm{~m}$ $89 / 429$ and $94 / 67$. Without Community provisions for landfills, there is a considerable risk that shipments of waste will increase in order to bring waste to landfill, which now - in the absence of appropriate environmental standards - is considerably less expensive. Such shipments would also go against the objective of Regulation 259/93 which seeks to reduce, as far as possible, all waste shipments.

\section{Subsidiarity}

The Directive is compatible with the principles of subsidiarity. It seeks to introduce uniform standards for landfilling throughout the Union. Different national standards would not only increase the present divergence in environmental standards between certain regions of the community but could also stimulate increased shipments of waste within Europe. This will not 
encourage sound waste management in those regions of the Community where it is most needed.

The introduction of limits for landfilling of biodegradable waste in the new Directive also represents a high level of respect for the principle of subsidiarity . this Provision allows Member States to take account of local conditions. Thus, the Directive will allow Member States flexibility in choosing which way the reduction targets for landfilling of biodegradable waste are to be achieved. This flexibility is incorporated in order to ensure that Member states can apply the best option to meet their particular national conditions.

\section{NEW ELEMENTS}

1) Extracted from; Proposal for a Council Directive of Landfill Waste. Commission of the European Communities. Brussels, 05.03.1997 COM(97) 105 final

Since the Commission adopted the first Porposal in 1991, the waste management sector has developed extensively. New technologies a new knowledge about products and substances have put the focus on the necessity of waste reduction and waste prevention. This has resulted in a change of waste management procedures in the majority of Member States. In the light of these developments and the comments of the European Parliament a number of new elements have been introduced in the Directive. The most important elements are listed below.

\section{Reduction of the landfilling of biodegradable waste}

The Landfill Directive introduces provisions to reduce the landfilling of biodegradable waste and to ensure that the gases produced in new as well as existing landfills are collected, treated and used. Thus, a limit for the disposal of biodegradable waste has been introduced. This provision aims both at reducing the methane emissions from landfills and at encouraging the separate collection of biodegradable waste to reduce landfilling of waste in general. Thus, the reduction targets for the landfilling of biodegradable waste aims at promoting sorting in general, recovery and recycling. Several Member States have already introduced limits or guidelines for biodegradable waste going to landfills.

A recent study estimates the average $\%$ of biodegradable waste in municipal waste i Europe at $20-50 \%$. The introduction of a continuos phase out of biodegradable waste going to landfill will require Member States

to start establishing other waste management systems for biodegradable waste. However, in accordance with the principle of subsidiarity, member States will be allowed flexibility in choosing the way in which the reduction of landfilling of biodegradable waste is to be achieved. Biodegradable waste can be collected, sorted and then submitted to national composting facilities, biogas or incineration plants. Home-composting in rural areas can be introduced as well as in villa areas and multiple story houses. 


\section{Pre-treatment of waste before landfilling}

In line with the development and practices in several Member States and overall Community Waste Strategy. A provision is introduced which requires waste to be treated before it is landfilled. The purpose of this treatment is to reduce the volume or hazardous nature of the waste and thus to facilitate its handling and enhance recovery. Pre-treatment is defined as "the physical, chemical or biological processes, including sorting, that change the characteristics of the waste in order to reduce its volume or hazardous nature, facilitate its handling or enhance recovery". This broad definition of pre-treatment has been introduced to encourage methods other than incineration prior to landfilling of waste.

\section{Ban on disposal of used tyres}

The disposal of used tyres (whole and shredded) will be prohibited. The Priority Waste Stream Working Group on used tyres, which was set up by the Commission in 1991, proposed a ban on landfilling of tyres in its final conclusions of September 1993. This has been taken into account in the Proposal in order to prevent landfilled tyres from making the sites unstable and to reduce the risk of fire. The ban on landfilling of both whole tyres and shredded tyres will encourage the recovery of tyres and thus save resources.

\section{Increased cost of landfilling}

As reflected in the review of the Community Strategy on Waste Management, Member States should ensure that the price charged for the disposal of any type of waste in a landfill covers at a minimum all costs involved in the setting up and operation of the site. The price, however, should also include the cost of the financial security as well as the estimated costs of the closure and aftercare of the site for a period of at least 50 years. This provision aims at restoring the balance between the costs of landfilling of waste, which at present tend to bee too low, and the costs of other treatment methods, such as environmentally sound recovery operations, for which the costs are relatively high. In the Common Position it was stated that Member States had to ensure that the price to be charged for the disposal of any type of waste in a landfill should cover all costs involved in setting up and operation of the site. In the new Proposal, Member States are required to ensure that the costs also cover the closure and aftercare of the site.

\section{Remote areas}

Small islands with only one landfill and isolated settlements with difficult access - for these notions objective criteria have been fixed - may be exempted from some provisions of the Directive. Appropriate safeguards have been taken to ensure that exemptions are not used too widely and that the exempted areas are not being used for uncontrolled landfilling.

\section{ECONOMIC CONSIDERATIONS}

1) Extracted from; Proposal for a Council Directive of Landfill Waste. Commission of the European Communities. Brussels, 05.03.1997 COM(97) 105 final

The Directive is expected to generate significant environmental benefits in terms of reduced amounts of waste disposed in landfills and increased safety of landfills including lower methane emissions, reduced risk of leakages and less site disamenities. The achievement of 
these results will necessarily involve some economic consequences. These can be described in terms of static and dynamic costs. The directive requires that landfill installations comply with a number of technical standards, regardless of the waste volume going to the landfill .

These costs of building and operating landfill sites in compliance with the proposed measures represent the static impact. However, the Directive also has a wider scope than simply regulating the current practice of landfill. In conformity with the European Waste Strategy, the Directive aims at diverting waste from the bottom to the top of the waste hierarchy, that is from landfilling towards prevention and recovery. The costs of displacing landfill with more environmentally friendly options represent the dynamic impact.

The static costs engendered by the Directive depend on the way landfill sites are actually operated. A landfill site that is already properly managed is likely to incur little or no compliance costs. On the contrary unregulated or illegal landfill sites, whose building and operating costs by definition are practically zero, are bound to demand some finical resources to comply with the proposed measures. European average cost of landfill of municipal waste is about $32 \mathrm{ECU}$ per tonne in urban sites and $20 \mathrm{ECU}$ in rural sites (1993 prices). This difference is accounted for by the cost of land, which is by far the most important cost element

It is clear, however, that Member States presently relying almost entirely on landfilling will have to make more efforts to meet the targets. On the other hand, Member States, that already have reduced their use of landfilling will be in line with the Directive objectives and will therefore not incur any additional costs. Finally, there is a group of Member States that recently have introduced forwards looking national waste management strategies to reduce the use of landfilling. For these the net costs that, may result from the implementation of this Directive will only represent the difference between what the objective of the Directive require and what the Member States have planned already.

The implementation of the Directive will generate several economic as well as environmental advantages. First, the diversion of waste away from landfill and into other waste treatment methods will reduce both ground water and soil pollution and restoration and clean up costs. This will also result in reduced resource costs and - with increased recycling - more opportunities for eco-businesses. The investments in alternative waste treatment facilities such as composting plants, recycling an incineration will also create increased employment opportunities. Secondly, the Directive will result in a reduction of methane emissions. As discussed, the global warming potential of methane is significantly higher than the GWP for $\mathrm{CO}_{2}$. Reduction of biodegradable waste is a cost effective way of contributing to the reduction of global warming. Moreover methane recuperation for energy generation is also encouraged by the Directive. Finally, the Directive reduce the disamenities connected with current landfill practices.

\section{THE LITHUANIAN EXAMPLE}

1) Extracted from; Costs of approximating Lithuanian Environmental Legislation with the European Union. Final Report. Ministry of Environmental Protection of the Republic Lithuania 
A Technical Assistance project to support the process of integration of the environmental sector in Lithuania has focused on the costs of approximating the Lithuanian Environmental Legislation with the legislation in the European Union. In one of the chapters the development of expenditures for waste management is discussed for the period up to the year 2020 . During the first half of that period all existing landfills will reach their available capacity. Expenditures for establishing new landfills parallel to the closure of old ones.

In table 1 only amortised capital costs are included because in this analysis operating costs associated with closed landfills is assumed to be zero.

Table 1 Costs of landfill closures (MECU)

\section{Cumulative Investments}

Gas extraction

Capping

Fencing

Total Cumulative Investment

Annualised Capital Cost

Five Year Period Ending

$2000 \quad 2005 \quad 2010 \quad 2015 \quad 2020$

$\begin{array}{lllll}1.5 & 6.2 & 6.2 & 6.2 & 6.2 \\ 21.2 & 87.3 & 107.1 & 107.1 & 107.1 \\ 0.9 & 3.6 & 3.6 & 3.6 & 3.6 \\ 23.6 & 97.1 & 116.9 & 116.9 & 116.9 \\ 3.2 & 13.2 & 15.9 & 15.9 & 15.9\end{array}$

As shown in Table 2 the investments and annualised costs of organic waste recovery are also significant. By 2010, for example, over ECU 100 million will have invested. Annualised costs are expected to be approximately ECU 41 million.

Table 2 Costs of organic waste recovery (1996 MECU)

Cumulative Investment

Year

$\begin{array}{lllll}2000 & 2005 & 2010 & 2015 & 2020\end{array}$

Annualised Costs

$\begin{array}{lllll}15.7 & 50.2 & 102.1 & 150.5 & 150.5\end{array}$

$\begin{array}{lllll}5.4 & 18.5 & 40.7 & 53.2 & 53.2\end{array}$

It should be emphasised that there are also important economic benefits associated with organic waste recovery that do not show up explicitly as monetary benefits, but which are implicit in the calculations. Because landfilled waste is reduced as a result of this component of the directive, landfill lifetime are extended and landfill sizes are reduced. This saves municipalities resources. Similar benefits are also derived from 94/62/EEC (Directive on Packaging Waste) and are included in the analysis as avoided upgrading a replacement of landfills.

In addition, packaging waste, compost and manure can be sold. Similarly, wood waste can be used for a variety of purposes, including mulch, particle board and fuel, depending on the material and the circumstances. The revenues from packaging waste are considered in the next section of this report, but any sales of organic products are not included in the analysis. This assumption implies that the costs of organic waste recovery are probably somewhat overstated. 
As shown in Table 3, instituting these two recovery and (partial) recycling requirements significantly reduce the amount of waste to be landfilled. For example, in 2010, instead of landfilling 2792 thousand tons, only 1964 thousands tons are expected to be landfilled. This reduction represents a saving of $\mathrm{t} 30 \%$.

Table 3 Total landfilled waste with and without recovery and recycling (in thousand tons/yr)

$\begin{array}{lllll} & 2000 & 2005 & 2010 & 2015 \\ \text { Waste without recovery and recycling } & 1989 & 2356 & 2792 & 3402 \\ \text { Waste with recovery and recycling } & 1874 & 1806 & 1964 & 2388 \\ \text { Annual reduction due to recovery and } & 115 & 550 & 829 & 1013\end{array}$
recycling

Even with the benefits of recycling, however, the costs of upgrading and constructing new landfills is also expected to be rather large. By 2005, approximately ECU 135 million will have been invested, and by 2010 investments should total about ECU 190 million . On an annualised basis, costs are expected to rise from ECU 42 million in 2000 to ECU 65 million in 2005 and ECU 98 million in 2010.

Table 4 Costs of upgrading and constructing new landfills (MECU)

$\begin{array}{lll}\text { Five Year Period Ending } & \text { Cumulative Investment } & \text { Annualised Cost } \\ 2000 & 86.5 & 41.7 \\ 2005 & 135.5 & 64.9 \\ 2010 & 190.6 & 98.4 \\ 2015 & ? & ? \\ 2020 & \text { Same as 2015 } & \text { Same as 2015 }\end{array}$

The table below gives the total costs associated with complying with the directive, taking into account the economic benefits of organic waste recovery. As shown in Table 5 , to comply fully with the directive, by 2010 a total of ECU 307 million will have to be invested. This will impose an annual burden of ECU 114 million or $1.8 \%$ of 1996 GDP on the Lithuanian economy.

Table 5 Total costs of compliance with the Landfill Directive (1996 MECU)

$\begin{array}{lll}\text { Five Year Period Ending } & \text { Cumulative Investment } & \text { Annualised Cost } \\ 2000 & 125.8 & 50.3 \\ 2005 & 282.8 & 96.6 \\ 2010 & 348.2 & 155.0 \\ 2015 & 393.2 & 166 \\ 2020 & 393.2 & 166\end{array}$

Viewed from a per ton perspective, the costs are also expected to be very large. In the year 2000 the cost is expected to be approximately ECU 25 per ton. This figure increases to ECU 40 in 2005 and ECU 58 in 2010. If municipalities are unable to exploit economies-of-scale associated with regionalisation (hopefully an incorrect assumption), but want fully cover 
costs using monthly tariffs, large increase in rates may be required. It is also true, however, that if incentives for waste reduction are given, these increases in tariffs will reduce amounts of landfilled waste. This will imply that landfills will last longer (reducing annualised costs) or landfills can be smaller (also reducing costs).

It is clear from the analysis that this directive can in some years impose almost prohibitive costs on municipalities that are unused to major investments in this area. Because municipal finance in Lithuania is a major problem in general, careful attention to financial planning will be required. In particular, the degree to which tariffs can reasonably be raised needs to be evaluated, which suggests that some simple analysis of household willingness-to-pay for waste management upgrading may be useful.

\section{Waste management in the Baltic sea region}

1) Waste management around the Baltic sea. Nina Andgren, dept. of Technology, University of Kalmar, Sweden. 1999 (unpublished material)

In order to get a view about the waste management in the Baltic sea region information has been collected by questionnaires and from literature. The results are shown in table 6 to 8 . The cost for handling of the waste will increase in the future and this increase of costs will be higher in those countries that has no recycling plants, bad infrastructure for the waste management and no proper landfills and/or incinerators.

Table 6 Area and population

\begin{tabular}{|c|c|c|c|c|c|}
\hline Country & $\begin{array}{l}\text { Land area } \\
\left(\mathrm{km}^{2}\right)\end{array}$ & $\begin{array}{l}\text { Population } \\
\text { (millions) }\end{array}$ & $\begin{array}{l}\text { Percentage } \\
\text { living in } \\
\text { cities }\end{array}$ & $\begin{array}{l}\text { GDP per } \\
\text { capita (US\$) }\end{array}$ & $\begin{array}{l}\text { GDP Growth } \\
\text { rate }(\%)\end{array}$ \\
\hline Denmark & 43,000 & 5.3 & 83 & 23,200 & 3 \\
\hline Sweden & 450,000 & 8.9 & 87 & 19,700 & 2.1 \\
\hline Finland & 340,000 & 5.1 & 65 & 20,000 & 4.6 \\
\hline Estonia & 64,000 & 2.5 & 68 & 4,260 & 6 \\
\hline Latvia & 45,000 & 1.4 & 73 & 6,450 & 10 \\
\hline Lithuania & 65,300 & 3.7 & 68 & 4,230 & 6 \\
\hline Poland & 310,000 & 38.6 & 62 & 7,250 & 6.9 \\
\hline Germany & 357,000 & 81.5 & 87 & 20,800 & 2.4 \\
\hline
\end{tabular}


Table 7 Type of waste and quantities

\begin{tabular}{|c|c|c|c|c|c|c|}
\hline Country & $\begin{array}{l}\text { MSW } \\
\text { tons per }\end{array}$ & $\begin{array}{l}\text { Hazardous } \\
\text { w. }\end{array}$ & $\begin{array}{l}\text { Total } \\
\text { waste }\end{array}$ & $\begin{array}{l}\text { Numbers } \\
\text { of }\end{array}$ & $\begin{array}{l}\text { Number of } \\
\text { compost }\end{array}$ & $\begin{array}{l}\text { Number of } \\
\text { incinerator }\end{array}$ \\
\hline & year & $\begin{array}{l}\text { tons per } \\
\text { year }\end{array}$ & $\begin{array}{l}\text { tons per } \\
\text { year }\end{array}$ & landfills & plants & $\mathrm{s}$ \\
\hline Denmark & $2,610,000$ & 252,000 & $9,600,000$ & 20 & 136 & 40 \\
\hline Sweden & $3,678,000$ & 250,000 & $7,500,000$ & 300 & 120 & 21 \\
\hline Finland & $2,320,000$ & - & . & 366 & 40 & 1 \\
\hline Estonia & 955,000 & $7,679,000$ & $=$ & 371 & 0 & 0 \\
\hline Latvia & 284,000 & 50,000 & - & 550 & 1 & 0 \\
\hline Lithuania & 140,000 & 100,000 & - & 800 & 3 & 0 \\
\hline Poland & $11,348,000$ & $4,800,000$ & - & - & - & 7 \\
\hline Germany & $40,000,000$ & $9,000,000$ & - & 2984 & - & $=$ \\
\hline
\end{tabular}

Table 8 Treatment of municipal waste

\begin{tabular}{|c|c|c|c|c|c|}
\hline Country & $\begin{array}{l}\text { Recycling } \\
\text { and others } \\
(\%)\end{array}$ & $\begin{array}{l}\text { Incineration } \\
(\%)\end{array}$ & $\begin{array}{l}\text { Composting } \\
(\%)\end{array}$ & $\begin{array}{l}\text { Landfilling } \\
(\%)\end{array}$ & $\begin{array}{l}\text { Cost } \\
\text { treatment } \\
\text { year } 2000\end{array}$ \\
\hline Denmark & 5 & 19 & 60 & 16 & \\
\hline Sweden & 16 & 42 & 3 & 39 & \\
\hline Finland & 30 & 2 & 3 & 65 & \\
\hline Estonia & $=$ & $=$ & $=$ & $=$ & \\
\hline Latvia & - & 0 & 1 & 99 & \\
\hline Lithuania & + & 2 & 1 & 99 & \\
\hline Poland & 2 & + & - & 98 & \\
\hline Germany & 24 & 18 & 6 & 52 & \\
\hline
\end{tabular}

\section{References}

Notes in the text refers to the reference number

1. Utrikespolitiska Institutet, 1996, Länder i fickformat nr 415,416,418, 419, 506-509, Stockholm

2. CIA, 1999, World Factbook 1998, http://www.odci.gov/cia/publications/factbook/countryframe.html

3. Stockholm Environmental Institute, 1996, Environmental Implications of EU Membership of Estonia, Latvia, Lithuania and Poland: An Assessment of the Present Situation and the Issues and Problems involved in the Approximation Process, http://www.balticregion.net/environ/wast app.htm

4. Fammler H., Veidemane K., Simanovskaand J. and Platniece A. (ed), Baltic State of the environment Report, based on environmental indicators. The Web version, http://www.bef.lv/baltic/HTML/Chapt3.htm

5. By email from Maria Spole, 1999, head of Implementation Unit National Programme "500" in Latvia 
6. Kamienski. Z., 19999, The Sate of the Environment in Poland, http:nfppl.eionet.eu.int/SoE/wwwang/opad

7. Environmental Protection Ministry of the Republic of Lithuania, 1995, Lithuaniats Environment, Status, Porocess, Trends, Vilnius

8. Moe. M.. 1995. Environmental Administration in Denmark, htu2: www.mst.dk/books/moe/23.htm

9. German Federal Environmental Agency, 1998, Landfill,

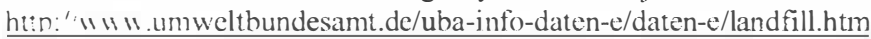

10.German Federal Environmental Agency, 1998, Waste law, htip: : ww.umweltbundesamt.de/uba-info-daten-e/daten-e/waste-law.htm

11.Hämäläinen. K.(Ministry of the Environment), 1999, Waste act, htun: " $\lll$ w. wh.fi/eng/environ/legis/wasteact.htm

12. Melanen. M. (Finnish Environment Institute), 1999, Research and development programme of environmental administration 1998-2000, ht:n: wwwawh hi/eng/research/r\%5Fdprog/partpro5.htm

13.Finnish local government services, 1999, http:/www.kuntaiiitto.fi/esittelv/environ.html

14.Hämäläinen. K.(Ministry of the Environment), 1999, Economic instruments for waste management, http://www.vyh.fi/eng/environ/econinst/econotax.htm

15.Svenska Renhållningsverksföreningen, Svensk avfallshantering 1998, hup: wwu.rvf.se/frame avt.html

16. Rendan-Videncenter for Affaldsminimiering \& Genanvendelse, 1997, hus: wwirendan.dk/

17.The European Topic Center on Waste, 1998, The data-warehouse used as background information in writing the waste chapter to report: The State of the Environment in EU 1998

18.Survey made by Hogland. W. and Paulsson. B., 1998, Lund Institute of Technology, Sweden

19.Committie of environment protection of Sankt-Petersburg and Leningrad region, 1997, hin: " w dux.ru/lcp/L.E 2OTX.HTM

20.Boiartchouk. N. and Netchistiak. T., 1998, Solid waste Management I Moscow, SWECO, Stockholm. Sweden

21.Vidużs. A., 1998, 1995 Conception on municipal waste management in Latvia, SWECO, Stockholm, Sweden

22.Bendere. R.. 1998, Municipal Solid Waste management In Latvia. The present condition and future Strategy, SWECO, Stockholm, Sweden

23.Meier. E., 1998, Condition of waste treatment and application of new treatment methods in healthcare institutions of Tallinn, SWECO, Stockholm, Sweden

24.Blindziuviene. D., 1998, No titel, SWECO, Stockholm, Sweden

25.Olsewska. B. and Trojnarski. J., 1999, Municipal waste management in the region of Olztyn, in Solid waste management in Eastern Europe 1998-1999, SWECO, Stockholm, Sweden

26.Delinn. A., 1999, Inventory of solid household waste in Ventsoils city and district, Latvia, in Solid waste management in Eastern Europe 1998-1999, SWECO, Stockholm, Sweden

27.Zakka. S. and Berzinš. U., 1999, Waste management in Valmiera region, in Solid waste management in Eastern Europe 1998-1999, SWECO, Stockholm, Sweden

28.Vidužs. A., 1999, Systems approach and methods of solid waste management development, in Solid waste management in Eastern Europe 1998-1999, SWECO, Stockholm, Sweden 
29.Brazas. A., 1999, Observations regarding waste management regulation, organization and municipal waste management schemes (options), in Solid waste management in Eastern Europe 1998-1999, SWECO, Stockholm, Sweden

30.Slepikaite.D., 1999, Waste management in Vilnius municipality, in Solid waste management in Eastern Europe 1998-1999, SWECO, Stockholm, Sweden

31.Oleksands. B., 1999, Solid waste minimization, in Solid waste management in Eastern Europe 1998-1999, SWECO, Stockholm, Sweden

32.Demidova. O., 1999, Solid waste minimization, in Solid waste management in Eastern Europe 1998-1999, SWECO, Stockholm, Sweden

33.Cudeckis. V., 19999, Conception of organization of solid waste collection in Riga city. The project of Transfer stations, in Solid waste management in Eastern Europe 1998-1999, SWECO, Stockholm, Sweden

34.Chekalin. V., 1999, Project of complex managerial system by municipal waste in city, in Solid waste management in Eastern Europe 1998-1999, SWECO, Stockholm, Sweden

35.Naktinis. A., 1995, Wastes. Waste inventory and Management, http://neris.mii.lt/aa/an95/aat $1811 . \mathrm{html}$

36.By email from Rainio. K., 1999 Finnish Environmental Institute 